\title{
Purchasing Behavior for Skin Care Products by Distribution Channel
}

\author{
Sun-Hee Jeong \\ Department of Beauty Art, Suwon Women's University, Suwon-si, Gyenggi-do, Korea
}

Corresponding author: Sun-Hee Jeong, Department of Beauty Art, Suwon Women's University, 72 Onjeong-ro, Gwonseon-gu, Suwon-si, Gyeonggi-do 16632, Korea

Tel.: +82 312908375

Fax: +82312908030

Email: sunheejeong@swc.ac.kr

Received September 12, 2018

Revised October 3, 2018

Accepted October 18, 2018

Published December 30, 2018

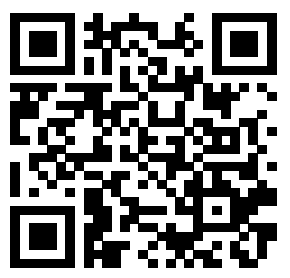

\begin{abstract}
Purpose: The purpose of this study was to explore the purchasing behavior for skin care products by distribution channel. Methods: Following a literature review, a questionnaire was distributed to women who live in Seoul and Kyeonggi-do in August 2018. 107 questionnaires were analyzed using Statistical Package for the Social Sciences. Chi-square $\left(\mathrm{X}^{2}\right)$ cross and ANOVA analysis were performed to determine the preferred distribution channel differences by respondent age. Results: Overall, respondents prefer online shopping because the price is reasonable. Respondents in their 20 s answered in favor of road shops while those in their 30s, 40s, and 50s answered in favor of online shops. In terms of preference, reliability, satisfaction, and loyalty by distribution channels, the online shop was considered the best for preference and reliability while the department store was considered the best for satisfaction and loyalty. Conclusion: The findings in this study provide implications for marketing skin care products based on purchasing behavior by distribution channel and can be used as basic research data for the industrial marketing of skin care products.
\end{abstract}

Keywords: Skin care products, Distribution channel, Purchasing behavior, Online shopping, Department store

\section{Introduction}

화장품은 해방 이후 가내공업으로 생산이 시작된 이래, 현재 국민 1 인당 소득의 증가로 화장품 산업이 급신장세를 보였다. 2014년 우리나라의 화장품 시장규모는 8조 1,778 억원이었으 며, 2014년 화장품 산업의 GDP증가율에서는 국내 GDP 증가율 (3.9\%) 및 제조업 증가율 $(1.6 \%)$ 보다 횔씬 높은 $12.5 \%$ 를 차지 하여 다른 분야에 비해 매우 높은 성장률을 보이고 있다(Park \& Sun, 2017). 소비계층도 여성에서 학령기 아동 및 남성까지 확 대되고 있고, 경제적으로도 풍족한 노인 인구의 증가로 수요계 층이 점차 확대되고 있다(Jo, 2007; Shin \& Kim, 2007). 국내 시장은 브랜드샵 위주의 고 성장세, 온라인 채널의 확대, 화장품 사용자의 확대를 바탕으로 지속적인 성장을 이루어 왔다. 또한 화장품은 기호성과 유행성이 강하며 제품의 수명이 짧아 신상품 개발이 번번히 이루어 진다. 따라서, 무수한 화장품 브랜드들 중 에서 소비자는 제한된 자원과 시간을 가지고 최적의 구매를 위한
노력을 하고 있다고 볼 수 있다. 현재 도처하고 있는 새로운 구매 환경 속에서 최선의 판단으로 구매를 결정하기 위해 소비자 스스 로 구매정보의 적극성과 노력이 필요로 되고 있다.

화장품 산업은 생산, 유통, 판매, 광고 및 소비에 이르기까 지 마케팅의 모든 부분이 복잡하고 유기적으로 연결되어 있다 (Frazier \& Rody, 1991; Moschis, 1976; Wilkinson, 1981; Westbrook \& Black, 1985). 화장품 유통채널은 단순한 판매 와 구매가 이루어지는 교환 경제 활동의 장소뿐만 아니라 기업 의 총체적 마케팅 전략을 적극적으로 수행할 수 있는 커뮤니케이 션 요소라 할 수 있다(Chun et al., 2013; Sun \& Yoo, 2004; Rosenberg, 1974). 유통채널이란 소비자가 제품이나 서비스에 대한 정보를 접하고 구매하는 쇼핑의 공간을 의미하며, 제품을 적절한 시기에 합리적인 가격으로 소비자에게 제공하여 소비자 들의 생활수준을 향상시키는 기능을 담당하고 있다( Anderson \& Narus, 1984; Frazier \& Rody, 1991; Park et al., 2015; Zeithaml et al., 1996). 한국 유통업의 경우, 1990년대에 들어 
서 대규모 자본이 유통업에 대거 투입됨에 따라 유통의 산업화 가 빠르게 나타났다(Hwang \& Shin, 2016; Lee et al., 2009). 과거의 화장품 산업이 전통적인 고부가치산업으로 다품종 소량 생산체계, 독점적인 경쟁구조, 해외의존도가 높은 원재료 등의 특징을 가지고 있다면, 최근 수입브랜드의 국내진출, 중저가 화 장품의 소비자 인식 변화와 함께 화장품 유통시장의 전면개방과 인터넷 발달 및 정보기술을 활용하는 고효율, 대규모 소매 형태 의 할인점의 폭발적 증가, 소비문화의 질적 향상으로 면세점, 약 국, 피부과, 피부관리실, 홈쇼핑 등 화장품 유통채널도 나날이 다양하게 발전하고 있다(Chun \& Park, 2012; Zhang et al., 2011). 또한 과거 20세기에는 화장품 유통채널이 오프라인에 국 한되었으나, 현재 온라인 분야까지 급 확장 되었다(Jung \& Jin, 2003 ; Kim \& Ha, 2010; Park \& Kim, 2008).

이와 같이 나날이 전문화 그리고 다양화 되는 화장품 유통경로 의 변화는 소비자의 소비행동에까지 영향을 미치고 있다. 소비자 중심의 마케팅 전략에서 소비자가 화장품 구매를 위해 특정 유통 채널을 반복적으로 선택하는데 주의를 두고, 특정 유통채널에서 화장품을 구매하는 소비자는 그 유통채널의 중요한 시장이 된다 고 볼 수 있다. 따라서, 소비자가 자주 이용하는 유통채널과 그 와 관련된 화장품 구매 행동 정보는 날로 경쟁이 치열해지는 유 통 환경에서 고객 만족도 향상을 통한 경쟁력 확보를 위해 매우 중요하다고 본다. 특히, 화장품 시장에서 기초화장품의 생산비중 이 가장 높은바, 소비자에게 기초화장품의 품질 및 서비스를 보 다 효율적으로 판매하기 위한 유통채널 별 소비자의 선호도, 신 뢰도, 만족도, 충성도 등을 연구하고자 한다.

\section{Methods}

\section{1. 연구대상 및 자료수집}

본 연구는 기초화장품의 유통채널 별 소비자의 선호도, 신뢰
도, 만족도, 충성도를 알아보는 것이 본 연구의 목표이다. 이를 위해 20 대에서 50 대 여성 중 기초화장품 구매경험이 있는 사람 들을 대상으로 설문조사를 실시하였다. 설문대상자는 서울, 경 기지역의 사람들을 대상으로 편의 표집하였으며, 연구자가 2018 년 8월10일부터 25 일 기간 동안 설문참여에 동의한 120 명에게 연구의 목적 및 필요성에 대해 설명한 후 설문지를 배포하였으 며, 설문응답은 설문문항에 대해 응답자들이 직접 작성하는 자기 기입식 방식을 통해 작성하였다. 이러한 과정을 통해 최종적으로 111 부의 설문지를 회수하였으며, 회수된 설문지 중 응답이 완전 하지 않은 4 부의 설문지를 제외한 총 107 부의 설문지를 최종분 석에 사용하였다.

\section{2. 연구도구}

본 연구의 설문지는 화장품 유통채널에 관한 선행연구들에 서 사용한 측정항목들을 바탕으로 본 연구에 적합하게 연구자가 수정 및 보완하여 재구성하였다. 구체적으로 일반적 특성에 대 한 3 개 문항과 화장품 유통채널을 선호하는 이유의 중요도에 대 한 5 개 문항을 비롯해 화장품 유통채널별 선호도와 신뢰도, 만족 도, 그리고 충성도는 Morgan \& Hunt (1994)와 Sirohi et al. (1998), 그리고 Hwang \& Lee (2011)의 설문문항을 참고하여 각각 3 개의 문항으로 구성하였다.

\section{3. 자료처리 및 분석방법}

설문조사를 통해 수집된 자료의 통계분석을 위해 데이터 코딩 (data coding)과 데이터 클리닝(cleaning) 과정을 거쳐, SPSS (WIN 23.0; IBM, USA) 통계패키지 프로그램을 활용하였다. 구 체적으로 응답자들의 일반적 특성에 대한 빈도 및 백분율을 확인 하기 위한 빈도분석을 비롯해, 주요변수들의 평균 및 표준편차 등을 확인하기 위한 기술통계량 분석, 연령에 따른 선호하는 유 통채널의 차이를 확인하기 위한 카이제곱검정 $\left(x^{2}\right)$ 교차분석, 연 령에 따른 유통채널의 선호이유의 중요도 차이를 확인하기 위한

Table 1. General characteristics

\begin{tabular}{|c|c|c|c|}
\hline Classification & & Frequency (N) & Percentage (\%) \\
\hline \multirow{4}{*}{ Age (years) } & $20-29$ & 35 & 32.7 \\
\hline & $30-39$ & 26 & 24.3 \\
\hline & $40-49$ & 22 & 20.6 \\
\hline & $50-59$ & 24 & 22.4 \\
\hline \multirow{4}{*}{ Job } & Salary men & 14 & 13.1 \\
\hline & Businessmen & 11 & 10.3 \\
\hline & Housewives & 28 & 26.2 \\
\hline & Students & 42 & 39.3 \\
\hline \multirow{4}{*}{ Monthly average income } & 1-2 million won & 13 & 12.1 \\
\hline & 2-3 million won & 15 & 14.0 \\
\hline & 3-4 million won & 23 & 21.5 \\
\hline & 4-5 million won & 36 & 33.6 \\
\hline
\end{tabular}


일원배치분산분석(one-way ANOVA) 등을 실시하였다.

\section{Results and Discussion}

\section{1. 연구대상자의 일반적 특성}

본 연구에 참여한 연구대상자의 일반적 특성은 Table 1 과 같다. 먼저 응답자의 연령을 살펴보면 20 대 응답자가 35 명 $(32.7 \%), 30$ 대 26명(24.3\%), 40대 22명(20.6\%), 50대 24명 (22.4\%)으로 20 대 응답자가 가장 많았으며, 직업유형은 직장인 14 명 $(13.1 \%)$, 자영업 11 명(10.3\%), 전문직 12 명(11.2\%), 주부 28 명 $(26.2 \%)$, 학생 42 명 $(39.3 \%)$ 으로 나타났다. 그리고 응답자 의 월 가구 소득은 400 만원에서 500 만원 미만인 응답자가 36 명 (33.6\%)으로 가장 많았으며, 300 만원에서 400 만원 미만 23명 (21.5\%), 500만원 이상 20명(18.7\%), 200만원에서 300만원 미 만 15명(14.0\%), 100만원에서 200만원 미만 13명(12.1\%) 순으 로 나타났다.

\section{2. 선호하는 화장품 유통채널 및 선호이유의 중요도}

기초화장품 유통채널의 선호도에 대한 빈도분석 및 선호이 유의 중요도에 대한 기술통계분석을 실시한 결과는 Table 2 와 Table 3 와 같다. 구체적으로, 본 연구에 참여한 응답자들의 선호 하는 유통채널에 대해 분석한 결과 온라인 유통채널을 선호한다 는 응답자가 51명(47.7\%)으로 가장 많았으며, 백화점 유통채널 을 선호한다는 응답자가 35 명(32.7\%)으로, 로드샵 유통채널을
선호한다는 응답자 21명(19.6\%) 순으로 나타났다(Table 2).

그리고 구체적으로 선택한 유통채널을 선호하는 이유의 중 요도를 살펴보면 로드샵 유통채널은 선호하는 유통채널의 평판 이(4.67점), 백화점 유통채널은 선호하는 유통채널의 서비스가 (4.63점), 온라인의 경우 판매하는 화장품 가격이(4.53점) 가장 중요함을 확인할 수 있다(Table 3). 이는 Sun \& Yoo (2004) 연 구에서 나타난 바와 같이 유통채널에 따라 명확히 중요시하는 요 인이 있음을 알 수 있었다.

\section{3. 연령대별 선호 유통채널 및 선호이유의 중요도}

20-50대 연령대별 여성의 선호하는 유통채널을 살펴본 결 과는 Table 4 와 같다. 분석결과를 살펴보면, 20 대의 경우 선호 하는 유통채널이 로드샵이라고 응답한 사람이 15 명으로 전체의 $42.9 \%$ 로 가장 많았으며, 백화점이라고 응답한 사람도 $37.1 \%$ 로 나타났다. 이는 Park (2013) 연구와 같이 20대의 화장품 선택이 가격에 치우치기 보다는 다양한 욕구에 의해 선택함을 알 수 있 는 결과이다. 반면 30 대는 전체의 $65.4 \%$ 가 선호하는 유통채널 로 온라인이라고 응답하였으며, 40대와 50대 역시 선호하는 유 통채널이 온라인이라는 응답자가 각각 $59.1 \%, 58.3 \%$ 를 차지하 여 가장 많음을 확인할 수 있다. 그리고 연령대에 따라 선호하는 유통채널이 통계적으로 유의한 차이가 있는가를 확인하기 위해 $x^{2}$ 검정을 실시한 결과, $x^{2}=24.789$ ( $\left.p<0.001\right)$ 으로 나타나 연령 대에 따라 선호하는 유통채널의 차이는 통계적으로 유의한 차이 가 있음을 확인할 수 있다.

한편, 선호하는 유통채널에 대한 연령대별 선호이유의 중요도

Table 2. Preferred distribution channel

\begin{tabular}{llcc}
\hline Division & & Frequency (N) & Percentage (\%) \\
\multirow{2}{*}{$\begin{array}{l}\text { Preferred distribution } \\
\text { channel }\end{array}$} & Road shop & 21 & 19.6 \\
& Department store & 35 & 32.7 \\
& Online shop & 51 & 47.7 \\
\hline
\end{tabular}

Table 3. Important factors of distribution channels

\begin{tabular}{|c|c|c|c|c|}
\hline Division & & $\begin{array}{l}\text { Road shop } \\
(\mathrm{N}=21)\end{array}$ & $\begin{array}{c}\text { Department store } \\
(\mathrm{N}=35)\end{array}$ & $\begin{array}{c}\text { Online shop } \\
(N=51)\end{array}$ \\
\hline \multirow{5}{*}{ Important factors } & Price & $4.48(0.60)$ & $4.03(0.82)$ & $4.53(0.58)$ \\
\hline & Convenience & $4.24(0.62)$ & $4.06(0.80)$ & $4.45(0.73)$ \\
\hline & Awareness & $4.67(0.58)$ & $4.43(0.50)$ & $4.18(0.59)$ \\
\hline & Service & $3.81(0.81)$ & $4.63(0.55)$ & $4.12(0.71)$ \\
\hline & Hospitality & $3.86(0.91)$ & $4.57(0.70)$ & $4.12(0.82)$ \\
\hline
\end{tabular}

Table 4. Preferred distribution channel by ages

\begin{tabular}{|c|c|c|c|c|c|c|}
\hline \multirow{2}{*}{ Divisions } & \multicolumn{4}{|c|}{ Ages } & \multirow{2}{*}{ Total } & \multirow{2}{*}{$x^{2}(\rho$-value $)$} \\
\hline & $20 \mathrm{~s}$ & 30s & $40 \mathrm{~s}$ & 50s & & \\
\hline Road shop & 15 (42.9\%) & $0(0.0 \%)$ & 3 (13.6\%) & 3 (12.5\%) & $21(19.6 \%)$ & \\
\hline Department store & $13(37.1 \%)$ & $9(34.6 \%)$ & $6(27.3 \%)$ & 7 (29.2\%) & 35 (32.7\%) & $24.789(0.000)$ \\
\hline Online shop & 7 (20.0\%) & $17(65.4 \%)$ & $13(59.1 \%)$ & $14(58.3 \%)$ & $51(47.7 \%)$ & \\
\hline Total & $35(100.0 \%)$ & $26(100.0 \%)$ & $22(100.0 \%)$ & $24(100.0 \%)$ & 107 (100.0\%) & \\
\hline
\end{tabular}


에 차이가 있는가를 확인하기 위해 일원배치분산분석을 실시하 였다. 먼저, Table 5에서 로드샵 유통채널을 선호한다고 응답한 21 명을 대상으로 유통채널 선호이유의 중요도에 대한 one-way ANOVA 분석을 실시한 결과를 살펴보면 로드샵을 선호하는 이 유의 중요도 중 가격, 평판, 판매원의 친절은 연령에 따라 통계 적으로 유의한 차이가 있는 것으로 나타났으나, 편의성과 서비스 는 연령에 따라 통계적으로 유의한 차이가 없음을 확인할 수 있 다. 구체적으로 첫째, 로드샵 유통채널을 선호이유 중 가격의 중 요도와 관련하여 20 대 응답자의 평균은 4.53 점으로, 40 대 응답 자의 평균은 3.67 점으로, 50 대 응답자의 평균은 5.00 점으로, $F$ 값과 유의확률이 $5.805, p<0.05$ 으로 나타나 연령에 따른 가격의 중요도는 통계적으로 유의한 차이가 있음을 확인할 수 있었다. 그리고 연령에 따른 가격의 중요도 차이를 구체적으로 확인하기 위해 Scheffe test를 실시한 결과, 50 대와 20 대의 가격 중요도 가 40 대의 가격 중요도보다 높음을 확인할 수 있다. 둘째, 로드 샵 유통채널을 선호이유 중 평판의 중요도와 관련하여 20 대 응 답자의 평균은 4.87 점으로, 40 대 응답자의 평균은 4.00 점으로, 50 대 응답자의 평균은 4.33점으로, $F$ 값과 유의확률이 4.636, $p<0.05$ 으로 나타나 연령에 따른 평판의 중요도는 통계적으로 유 의한 차이가 있음을 확인할 수 있었으며, 연령에 따른 평판의 중 요도 차이를 구체적으로 확인하기 위해 Scheffe test를 실시한 결과, 20 대의 평판 중요도가 40 대의 평판 중요도 보다 높음을 확인할 수 있다. 셋째, 로드샵 유통채널을 선호이유 중 판매원 친절의 중요도와 관련하여 20 대 응답자의 평균은 3.60 점으로, 40 대 응답자의 평균은 5.00점으로, 50 대 응답자의 평균은 4.00 점으로, $F$ 값과 유의확률이 $3.857, p<0.05$ 으로 나타나 연령에 따 른 판매원 친절의 중요도는 통계적으로 유의한 차이가 있음을 확 인할 수 있었으며, 연령에 따른 판매원 친절의 중요도 차이를 구 체적으로 확인하기 위해 Scheffe test를 실시한 결과 20 대의 판
매원 친절의 중요도가 40 대의 판매원 친절의 중요도보다 높음을 확인할 수 있다.

다음으로, Table 6 에서 백화점 유통채널을 선호한다고 응답한 35 명을 대상으로 유통채널 선호이유의 중요도에 대한 one-way ANOVA 분석을 실시한 결과를 살펴보면 백화점을 선호하는 이유 의 중요도 중 편의성, 평판, 서비스는 연령에 따라 통계적으로 유 의한 차이가 있는 것으로 나타났으나, 가격과 판매원의 친절은 연 령에 따라 통계적으로 유의한 차이가 없음을 확인할 수 있다. 구 체적으로 첫째, 백화점 유통채널을 선호이유 중 편의성의 중요도 와 관련하여 20 대 응답자의 평균은 4.31점으로, 30 대 응답자의 평균은 3.67 점으로, 40 대 응답자의 평균은 3.50 점으로, 50 대 응 답자의 평균은 4.57점으로, $F$ 값과 유의확률이 $3.816, p<0.05$ 으 로 나타나 연령에 따른 편의성의 중요도는 통계적으로 유의한 차 이가 있음을 확인할 수 있었으나, 연령에 따른 편의성의 중요도 차이를 구체적으로 확인하기 위한 Scheffe test에서는 연령에 따 른 편의성의 중요도 차이는 통계적으로 유의한 차이가 없는 것으 로 나타났다. 둘째, 백화점 유통채널을 선호이유 중 평판의 중요 도와 관련하여 20 대 응답자의 평균은 4.54점으로, 30 대 응답자 의 평균은 4.33점으로, 40 대 응답자의 평균은 4.00점으로, 50 대 응답자의 평균은 4.71점으로, $F$ 값과 유의확률이 2.967, $p<0.05$ 으로 나타나 연령에 따른 평판의 중요도는 통계적으로 유의한 차 이가 있음을 확인할 수 있었으나, 연령에 따른 평판의 중요도 차 이를 구체적으로 확인하기 위한 Scheffe test에서는 연령에 따른 평판의 중요도 차이는 통계적으로 유의한 차이가 없는 것으로 나 타났다. 셋째, 백화점 유통채널을 선호이유 중 서비스의 중요도와 관련하여 20 대 응답자의 평균은 4.54 점으로, 30 대 응답자의 평 균은 5.00 점으로, 40 대 응답자의 평균은 4.00 점으로, 50 대 응답 자의 평균은 4.86점으로, $F$ 값과 유의확률이 $6.931, p<0.01$ 으로 나타나 연령에 따른 서비스의 중요도는 통계적으로 유의한 차이

Table 5. Importance difference of skin care products purchase at road shop by age

\begin{tabular}{llcccccc}
\hline Division & & $20 s(a)$ & $30 s(b)$ & $40 s(c)$ & $50 s(d)$ & $F$ & Scheffe \\
& Price & $4.53(0.52)$ & - & $3.67(0.58)$ & $5.00(0.00)$ & $5.805^{*}$ & $a, d>c$ \\
& Convenience & $4.33(0.62)$ & - & $4.33(0.58)$ & $3.67(0.58)$ & 1.543 & \\
Road shop & Awareness & $4.87(0.35)$ & - & $4.00(0.00)$ & $4.33(1.15)$ & $4.636^{*}$ & $a>c$ \\
& Service & $3.73(0.88)$ & - & $4.33(0.58)$ & $3.67(0.58)$ & 0.713 & \\
& Hospitality & $3.60(0.91)$ & - & $5.00(0.00)$ & $4.00(0.00)$ & $3.857^{*}$ & $a>c$ \\
\hline
\end{tabular}

${ }^{*} p<0.05$.

Table 6. Importance difference of skin care products purchase at department store by age

\begin{tabular}{llcccccc}
\hline Division & & $20 \mathrm{~s}(\mathrm{a})$ & $30 \mathrm{~s}(\mathrm{~b})$ & $40 \mathrm{~s}(\mathrm{c})$ & $50 \mathrm{~s}(\mathrm{~d})$ & $F$ & Scheffe \\
& Price & $4.31(0.75)$ & $3.67(1.00)$ & $3.50(0.55)$ & $4.43(0.53)$ & 2.866 \\
Department & Convenience & $4.31(0.63)$ & $3.67(1.00)$ & $3.50(0.55)$ & $4.57(0.53)$ & $3.816^{*}$ & \\
store & Awareness & $4.54(0.52)$ & $4.33(0.50)$ & $4.00(0.00)$ & $4.71(0.49)$ & $2.967^{*}$ & \\
& Service & $4.54(0.66)$ & $5.00(0.00)$ & $4.00(0.00)$ & $4.86(0.38)$ & $6.931^{* *}$ & $\mathrm{~b}, \mathrm{~d}>\mathrm{c}$ \\
& Hospitality & $4.23(0.93)$ & $5.00(0.00)$ & $4.50(0.55)$ & $4.71(0.49)$ & 2.604 & \\
\hline
\end{tabular}

${ }^{*} p<0.05 ;{ }^{* *} p<0.01$. 
가 있음을 확인할 수 있었으며, 연령에 따른 서비스의 중요도 차 이를 구체적으로 확인하기 위해 Scheffe test를 실시한 결과 30 대와 50 대의 서비스의 중요도가 40 대의 서비스의 중요도보다 높 음을 확인할 수 있다.

그리고, Table 7에서 온라인 유통채널을 선호한다고 응답한 51 명을 대상으로 유통채널 선호이유의 중요도에 대한 one-way ANOVA 분석을 실시한 결과를 살펴보면 온라인을 선호하는 이유 의 가격과 판매원의 친절은 연령에 따라 통계적으로 유의한 차이 가 있는 것으로 나타났으나, 편의성과 평판, 그리고 서비스는 연 령에 따라 통계적으로 유의한 차이가 없음을 확인할 수 있다. 구 체적으로 첫째, 온라인 유통채널을 선호이유 중 가격의 중요도와 관련하여 20 대 응답자의 평균은 4.29점으로, 30 대 응답자의 평 균은 5.00점으로, 40 대 응답자의 평균은 4.62점으로, 50대 응답 자의 평균은 4.00점으로, $F$ 값과 유의확률이 $15.105, p<0.001$ 으 로 나타나 연령에 따른 가격의 중요도는 통계적으로 유의한 차이 가 있음을 확인할 수 있었으며, 연령에 따른 서비스의 가격의 중 요도 차이를 구체적으로 확인하기 위해 Scheffe test를 실시한 결 과 30 대의 가격의 중요도가 20 대와 50 대의 가격의 중요도 보다 높음을, 40 대의 가격의 중요도가 20 대와 50 대의 가격의 중요도 보다 높음을 확인할 수 있다. 둘째, 온라인 유통채널을 선호이유 중 판매원 친절의 중요도와 관련하여 20 대 응답자의 평균은 3.43 점으로, 30 대 응답자의 평균은 3.94 점으로, 40 대 응답자의 평균 은 4.31점으로, 50 대 응답자의 평균은 4.50점으로, $F$ 값과 유의 확률이 $3.706, p<0.01$ 으로 나타나 연령에 따른 판매원 친절의 중 요도는 통계적으로 유의한 차이가 있음을 확인할 수 있었으며, 연 령에 따른 판매원 친절의 중요도 차이를 구체적으로 확인하기 위 해 Scheffe test를 실시한 결과 50대의 판매원 친절의 중요도가 20 대의 판매원 친절의 중요도보다 높음을 확인할 수 있다.

\section{4. 유통채널별 선호도, 신뢰도, 만족도 및 충성도}

유통채널별 선호도와 신뢰도, 만족도, 그리고 충성도의 기술
통계량 분석을 실시한 결과는 Table 8과 같다. 분석 결과를 살 펴보면, 첫째, 유통채널별 선호도는 로드샵의 평균점수가 3.97 점, 백화점의 평균점수가 3.68점, 온라인의 평균점수가 4.24점 으로 나타나 유통채널별 선호도는 온라인 유통채널이 가장 높음 을 확인할 수 있다. 둘째, 유통채널별 신뢰도는 로드샵의 평균점 수가 3.85 점, 백화점의 평균점수가 4.22 점, 온라인의 평균점수 가 4.28점으로 나타나 유통채널별 선호도 또한 온라인 유통채널 이 가장 높음을 확인할 수 있다. 셋째, 유통채널별 만족도는 로드 샵의 평균점수가 3.88점, 백화점의 평균점수가 4.43점, 온라인의 평균점수가 4.36점으로 나타나 유통채널별 만족도는 백화점 유통 채널이 가장 높음을 확인할 수 있다. 넷째, 유통채널별 충성도는 로드샵의 평균점수가 3.73점, 백화점의 평균점수가 3.76점, 온라 인의 평균점수가 4.26 점으로 나타나 유통채널별 충성도는 온라인 유통채널이 가장 높음을 확인할 수 있다. 이는 Sun \& Yoo (2004) 연구에서 나타난 바와 같이 온라인 유통채널은 대중매체 정보를 통해 비교가 용이하여 신뢰도가 높았고, $\operatorname{Kim} \& \mathrm{Oh}$ (2018) 연구 결과와 동일하게 구매접근의 편의성으로 인한 선호도가 높았다. 그리고, 전반적인 온라인 유통채널의 긍정적인 평가는 고객의 충 성도까지 반영되었다. 백화점은 고객유치를 위한 유통채널의 전 략적 노력으로 구매에 따른 서비스의 만족도가 높게 나왔다고 해 석할 수 있다.

\section{Conclusion}

본 연구는 빠르게 변화하고 있는 화장품 시장에서 20-50대 여성을 대상으로 기초화장품 구매 소비자의 유통채널별 구매행 동에 대해 분석하여, 소비자 만족도 향상을 통한 화장품 유통시 장을 활성화 하기 위해 실시하였다. 화장품 유통경로별 구매 경 향에 대한 분석을 통해 향후 화장품 기업의 효율적인 유통과 소 비자들의 소비 촉진을 도모하기 위한 마케팅에 도움이 되고자 연

Table 7. Importance difference of skin care products purchase at online shop by age

\begin{tabular}{llcccccc}
\hline Division & & $20 \mathrm{~s}(\mathrm{a})$ & $30 \mathrm{~s}(\mathrm{~b})$ & $40 \mathrm{~s}(\mathrm{c})$ & $50 \mathrm{~s}(\mathrm{~d})$ & $F$ & Scheffe \\
& Price & $4.29(0.76)$ & $5.00(0.00)$ & $4.62(0.51)$ & $4.00(0.39)$ & $15.105^{* * *}$ & $\mathrm{~b}, \mathrm{c}>\mathrm{a}, \mathrm{d}$ \\
& Convenience & $4.29(0.49)$ & $4.29(0.99)$ & $4.62(0.51)$ & $4.57(0.65)$ & 0.716 & \\
Online shop & Awareness & $4.43(0.53)$ & $4.24(0.44)$ & $4.23(0.83)$ & $3.93(0.47)$ & 1.372 & 1.031 \\
& Service & $4.00(0.82)$ & $3.94(0.90)$ & $4.38(0.51)$ & $4.14(0.53)$ & \\
& Hospitality & $3.43(0.79)$ & $3.94(0.90)$ & $4.31(0.75)$ & $4.50(0.52)$ & $3.706^{* *}$ & $\mathrm{~d}>\mathrm{a}$ \\
\hline
\end{tabular}

${ }^{* *} p<0.01 ;{ }^{* * *} p<0.001$.

Table 8. Preference, reliability, satisfaction and loyalty by distribution channels

\begin{tabular}{|c|c|c|c|c|}
\hline Division & Preference & Reliability & Satisfaction & Loyalty \\
\hline Road shop & $3.97(0.68)$ & $3.85(0.61)$ & $3.88(0.60)$ & $3.73(0.77)$ \\
\hline Department store & $3.68(0.79)$ & $4.22(0.49)$ & $4.43(0.38)$ & $3.76(0.57)$ \\
\hline Online shop & $4.24(0.75)$ & $4.28(0.66)$ & $4.36(0.63)$ & $4.26(0.70)$ \\
\hline
\end{tabular}


구하였다. 유통채널별 기초화장품 구매행동에 관한 연구결과는 다음과 같다.

첫째, 선호하는 유통채널을 분석한 결과 전반적으로 온라인 유 통채널의 선호도가 가장 높았고, 백화점, 로드샵 순으로 나타났 다. 구체적으로 소비자들이 유통채널을 선택하는 이유로, 로드샵 은 평판이, 백화점은 서비스가 그리고 온라인은 가격이 구매결정 에 있어 가장 중요함을 확인할 수 있었다. 둘째, 연령대별 선호 하는 유통채널을 분석한 결과, 20 대는 로드샵을 가장 선호하였 고, 30 대 -50 대는 온라인을 가장 선호함으로써 화장품 유통채널 이 온라인 분야까지 급 확장 되고 있음을 보여주었다. 20 대가 로 드샵을 가장 선호하는 이유중의 하나는 가격으로, 학생 그리고 사회초년생으로서 경제적인 요인이 화장품 구매행동에 있어 중 요하게 작용함을 알 수 있었다. 전반적으로 백화점 유통채널을 선호하는 소비자들은 편의성, 평판, 서비스를 중요시 하였고, 온 라인 유통채널을 선호하는 소비자들은 가격이 구매 결정에 중요 한 요인으로 작용하였다. 셋째, 유통채널별 선호도와 신뢰도, 만 족도 그리고 충성도의 기술통계량 분석에서는 온라인이 선호도, 신뢰도 그리고 충성도가 가장 높았고, 백화점이 만족도가 가장 높음을 확인 할 수 있었다. 온라인 유통채널은 구매접근의 편의 성으로 인한 선호도, 화장품 정보접근의 용이성으로 인한 신뢰도 그리고 전반적인 온라인 유통채널의 긍정적 평가로 높은 충성도 까지 반영되었다. 백화점은 고객유치를 위한 유통채널의 전략적 노력으로 구매에 따른 서비스의 만족도가 높음을 확인 할 수 있 었다.

본 연구의 결과, 화장품 유통채널의 다양화로 소비자들이 구매 할 수 있는 선택의 폭이 넓어져 연령대별로 유통채널 선택의 선 호 차이가 나타남을 볼 수 있었다. 본 연구는 각 기초화장품 유통 채널별로 구매행동의 원인을 분석함으로써, 점차 다양화되고 구 체화되고 있는 소비자의 요구에 맞추어 화장품 유통의 마케팅 방 향에 활용성이 있다고 사료된다.

\section{References}

Anderson JC, Narus JA. A model of the distributor's perspective of distributor-manufacturer working relationships. Journal of Marketing, 48: 62-74, 1984.

Chun TY, Park NH. The effect of TV home shopping channels trait on consumer trust, commitment and loyalty for hair and beauty product. Korea Logistics Review, 22: 247269, 2012.

Chun TY, Park NH, Park JS. The effect of purchase characteristics on positive emotion, relationship quality and repurchase in cosmetics on on-line shopping. Journal of Distribution and Management Research, 16: 121-131, 2013.

Frazier GL, Rody RC. The use of influence strategies in interfirm relationships in industrial product channels. Journal of Marketing, 55: 52-69, 1991.

Hwang JS, Lee JM. The effect which cosmetic brand shop experience marketing makes on brand satisfaction, attachment and loyalty. Jounal of the Korean Society of Cosmetology, 17: 1086-1096, 2011.

Hwang G, Shin SY. A study on adult women's-awareness of cosmetics distribution channels and purchase intention. Journal of Fashion Business, 20: 1-16, 2016.

Jung WJ, Jin YR. Evaluation of the characteristics of online shopping malls for cosmetics. Jounal of the Korean Society of Cosmetology, 9: 23-40, 2003.

Jo JG. A study on the development of Korean cosmetics industry. The Korean Journal of Health Economics and Policy, 13: 119-136, 2007.

Kim JA, Oh YK. Purchase behavior and satisfaction of onlineonly brand cosmetics. Asian Journal of Beauty and Cosmetology, 16: 32-41, 2018.

Kim JH, Ha JK. Purchase behavior and risk perception in cosmetics purchases at online shopping malls. Korean Journal of Human Ecology, 19: 1003-1012, 2010.

Lee JT, Kim SD, Song YW. A study on the historical evolution of channel structure of the cosmetics industry in Korea. The Review of Business History, 52: 157-175, 2009.

Morgan RM, Hunt SD. The commitment-trust theory of relationship marketing. Journal of Marketing, 58: 20-38, 1994.

Moschis GP. Shopping orientations and consumer uses information. Journal of Retailing, 52: 61-70, 93, 1976.

Park EJ, Kim JE. Relationships among shopping orientation, shopping-mall characteristics, consumer satisfaction, and loyalty in online market of cosmetics. The Research Journal of the Costume Culture, 16: 696-708, 2008.

Park SM. The study of cosmetics purchasing behavior act according to the transtheoretical model of the female university students. Asian Journal of Beauty and Cosmetology, 11: 351-359, 2013.

Park SH, Sun IS. An effect that conflict and relationship satisfaction in distribution channel has on loyalty and 
neglect: focusing on cosmetics industry. Journal of Distribution and Management Research, 20: 89-95, 2017.

Park SH, Yang HC, Sun IS. The effect of business relationships on conflict and satisfaction in the cosmetics industry's distribution channel. Journal of Distribution Science, 13: 79-86, 2015.

Rosenberg LJ. A new approach to distribution conflict management. Business Horizons, 17: 67-74, 1974.

Shin HJ, Kim JD. Purchasing behavior and orientation of cosmetic consumers by age group. Jounal of the Korean Society of Cosmetology, 13: 1130-1146, 2007.

Sirohi N, McLaughlin EW, Wittink DR. A model of consumer perceptions and store loyalty intentions for a supermarket retailer. Journal of Retailing, 74: 223-245, 1998.

Sun JH, Yoo TS. A study on shopping orientation, information source, store image of consumers according to the distribution channels of cosmetics. Journal of the Korean Society of Clothing and Textiles, 28: 559-569, 2004.

Westbrook RA, Black WC. A motivation-based shopper typology. Journal of Retailing, 61: 78-103, 1985.

Wilkinson IF. Power, conflict and satisfaction in distribution channels: an empirical study. International Journal of Physical Distribution and Logistics Management, 11: 20-30, 1981.

ZeithamI VA, Berry LL, Parasuraman A. The behavioral consequences of service quality. Journal of Marketing, 60: 31-46, 1996.

Zhang Y, Kang SC, Min D. Impact of CRM activities on behavioral intention through the relational benefits: a focus on the cosmetic industry. Journal of Information Technology Services, 10: 21-39, 2011. 


\section{국문초록}

\section{유통채널별 기초화장품 구매행동}

정선희

수원여자대학교 미용예술과, 경기도 수원시, 한국

목적: 본 연구는 유통채널별 기초화장품 구매 행동에 관한 연구를 하기 위함이다. 방법: 본 연구는 문헌조사와 서울 및 경기 지역 사 람들을 대상으로 설문조사를 통해 진행하였다. 총 107 부가 최종 분석에 사용되었으며, 통계분석은 SPSS 통계패키지 프로그램을 활 용하였다. 연령에 따라 선호하는 유통채널의 차이를 확인하기 위해 카이제곱검정 교차분석과 유통채널에 따른 선호이유의 중요도 차이를 확인하기 위해 일원배치 분산분석을 실시하였다. 결과: 응답자들은 온라인 쇼핑을 가장 선호하는 것으로 나타났으며, 이러 한 유통채널을 이용하는 이유를 합리적인 가격이라고 응답하였다. 연령별로는 20대의 경우 로드샵을 가장 선호하는 반면, 30-50대 는 온라인 쇼핑을 선호하였다. 유통채널별 선호도, 신뢰도, 만족도, 충성도에 관해서는 온라인 쇼핑의 선호도, 신뢰도, 충성도가 가 장 높았고, 백화점은 만족도가 가장 높았다. 결론: 본 연구는 유통채널을 통한 기초화장품 구매행동에 대한 마케팅에 영향을 줄 것 으로 기대되며, 기초화장품의 산업 마케팅을 위한 기초 연구에 활용될 수 있을 것이라 사료된다.

핵심어: 기초화장품, 유통채널, 구매행동, 온라인 쇼핑, 백화점

\section{참고문헌}

김주희, 하종경. 인터넷 쇼핑몰에서 화장품 구매시 위험지각에 따른 구매행동에 관한 연구. 한국생활과학회지, 19: 10031012, 2010.

김진아, 오윤경. 온라인전용 브랜드 화장품의 구매형태와 만족도. 아시안뷰티화장품학술지, $16: 32-41,2018$.

박선민. 여대생의 화장품 구매행동에 대한 범 이론적 모델을 적용한 비교 연구. 아시안뷰티화장품학술지, 11: 351-359, 2013.

박수홍, 선일석. 유통경로 상 갈등과 관계만족이 충성과 태만에 미치는 영향: 화장품 산업을 중심으로. 유통경영학회지, 20: 89-95, 2017.

박수홍, 양회창, 선일석. 코스메틱 산업에서의 유통경로상 거래관계가 갈등과 관계만족에 미치는 영향. 유통과학연구, 13 : 79-86, 2015.

박은주, 김지은. 화장품 온라인 시장에서 쇼핑 성향, 쇼핑몰 특성, 소비자 만족, 충성도의 관계. 복식문화연구, 16: $696-$ 708, 2008.

선정희, 유태순. 화장품 유통경로에 따른 소비자 쇼핑성향, 정보원, 점포이미지에 관한 연구. 한국의류학회지, 28: 559 569, 2004.

신혜진, 김주덕. 화장품 소비자의 연령별에 따른 구매 형태 및 성향. 한국미용학회지, 13: 1130-1146, 2007.

이종태, 김상덕, 송영욱. 한국화장품산업 유통경로의 역사적 발전. 경영사연구, 52: 157-175, 2009.

장원용, 강승철, 민대환. 고객 접점에서의 $\mathrm{CRM}$ 활동이 관계혜택을 매개로 행동의도에 미치는 영향. 한국IT서비스학회지, 10: 21-39, 2011.

전태유, 박노현. 이미용 상품을 대상으로 한 TV홈쇼핑 채널특성이 소비자신뢰와 관계결속 및 충성도에 미치는 영향. 물류 학회지, 22: 247-269, 2012.

전태유, 박노현, 박종삼. 온라인 쇼핑에서 화장품의 구매특성이 긍정적 감정, 관계품질 및 재구매의도에 미치는 영향. 유통 경영학회지, $16: 121-131,2013$.

정원정, 진유리. 인터넷을 이용한 화장품 쇼핑몰의 사이트별 특성비교. 한국미용학회지, 9: 23-40, 2003. 
조재국. 우리나라 화장품 산업의 발전방안. 보건경제와 정책연구, 13: 119-136, 2007.

황금빛누리, 신세영. 성인 여성의 화장품 유통채널별 인식도와 구매의도에 관한 연구. 패션 비즈니스, 20: 1-16, 2016.

황진숙, 이정민. 화장품 브랜드숍에서의 체험마케팅 유형이 브랜드 만족, 애착 및 충성도 형성에 미치는 영향. 한국미용학 회지, 17, 1086-1096, 2011. 


\section{中文摘要}

\section{分销渠道的基础化妆品购买行为研究}

鄭善熙

水原女子大学美容艺术科，京畿道水原市，韩国

目的：探索分销渠道的基础化妆品购买行为。方法：这项研究调查了对首尔和京畿地区的人员进行文献调查。 总共107份资料用于最终分析。使用SPSS统计软件包程序进行统计分析。为了根据年龄确定优选分配渠道的差 异, 进行检验卡方交叉分析 ; 为确定分销渠道的重要性差异, 进行了单因素方差分析。结果: 受访者更喜欢网上 购物, 并回答使用这种分销渠道的原因为价格合理。按年龄划分, 20多岁的人更喜欢路边商店, 而30-50多岁更 喜欢网购。对于分销渠道的偏好, 可靠性, 满意度和忠诚度, 网上购物具有最高的偏好, 可靠性和忠诚度, 而 百货商店的满意度最高。结论: 本研究预计将通过分销渠道影响基本化妆品购买行为的营销，可用于基础产品产 业营销的基础研究。

关键词: 基础化妆品，分销渠道，购买行为，网上购物，百货店 